\title{
COVID-19 PANDEMIC AS A CHALLENGE TO CULTURAL COOPERATION BETWEEN UKRAINE AND THE EU: PECULIARITIES AND PROSPECTS
}

\section{ПАНДЕМІЯ COVID-19 ЯК ВИКЛИК КУЛЬТУРНІЙ СПІВПРАЦІ УКРАЇНИ З ЄВРОПЕЙСЬКИМ СОЮЗОМ: ОСОБЛИВОСТІ ТА ПЕРСПЕКТИВИ}

\author{
Ivasechko O.Ya., \\ Associate Professor at the International Relations and Political Science Department \\ Lviv Polytechnic National University \\ Martsikhiv Kh.R., \\ Associate Professor at the Foreign Languages Department \\ Lviv Polytechnic National University \\ Kovalchuk A.Ye.,
Fourth year student at the Faculty of International Relations \\ Lviv Polytechnic National University
}

The article highlights the peculiarities of cultural cooperation between Ukraine and the EU since the moment of signing of the Association Agreement between Ukraine and the EU in 2014. It analyzes successfully implemented cultural projects under the official Brussels program "Creative Europe".

The attention is focused on the negative consequences caused by the COVID-19 pandemic, which have significantly affected the cultural dimension of the EU-Ukraine cooperation. It was also mentioned some differences in the change of priorities of the cultural sphere for the parties: comprehensive support of cultural industries in the countries of the Union and a significant reduction in funding for creative activities in Ukraine. The positive factors of these restrictions influence on the further development of intercultural communication between Ukraine and the EU member-countries, such as the rapid informatization of society and ideological integration between Ukrainian and the EU countries' citizens, are identified.

Recommendations for developing cultural interaction between the parties during the COVID-19 pandemic were given in the frames of three main objectives of the EU cultural policy such as preservation of cultural heritage, promotion of intercultural dialogue and development of cultural industries. As part of the preservation of cultural heritage issue, it is proposed to focus on the implementation of projects aimed at finding common historical and cultural ground with particular EU member-countries. The prospects of intercultural dialogue between Ukraine and the EU are considered to be promoted due to encouraging the formation of new links between representatives of educational institutions and non-governmental organizations. Regarding the development of cultural industries, it is mentioned the increase in the role of the IT sphere, which is able to ensure the transition of creative sector interactions in a new format accessible to the wide public.

It is concluded that cultural interactions between the official Brussels and Kyiv are characterized to have certain chaos, and therefore emphasized the requirements of systematic and proactive conducting of international dialogue with an involvement of wide public.

Key words: Ukraine, the EU, COVID-19, pandemic, culture, cultural cooperation, intercultural dialogue.

У статті висвітлено особливості культурної співпраці між Україною та ЄС з моменту підписання Угоди про асоціацію України з ЄС від 2014 р. Проаналізовано успішно імплементовані культурні проекти згідно з програмою офріційного Брюсселю «Креативна Європа».

Увагу сфокусовано на негативних наслідках, спричинених пандемією COVID-19, котрі істотно позначились і на культурному вимірі співпраці України-ЄС. Наголошено на ускладненні проведення міждержавних взаємодій, зокрема щодо культурного співробітництва між Україною та офріційним Брюсселем, що пов'язане із введенням карантинних обмежень. Відзначено відмінності в зміні пріоритетності культурної сфери для вказаних сторін, як-от всебічну підтримку культурних індустрій у державах Об'єднання та суттєве зменшення фінансування мистецької діяльності в Україні. Окремо визначено позитивні фактори впливу вказаних обмежень на подальший розвиток міжкультурної комунікації сторін, серед яких стрімка інформатизація суспільства та ідейна інтеграція між громадянами України та держав-членів ЄС.

Також запропоновано рекомендації та можливі траєкторії розвитку культурної співпраці між сторонами в умовах пандемії COVID-19 у контексті трьох ключових завдань культурної політики ЄС, як-от: збереження культурної спадщини, сприяння міжкультурному діалогу, розвиток культурних індустрій. У рамках сфери збереження культурної спадщини сторін запропоновано орієнтуватися на розроблення проектів, спрямованих на пошук історико-культурних спільностей з окремими державами ЄС. Відзначено перспективність інтенсифрікації міжкультурного діалогу між Україною та ЄС шляхом заохочення до фрормування нових зв'язків між представниками освітніх інституцій та неурядових організацій. Акцент зроблено на розвитку культурних індустрій та відзначено збільшення ролі IT-сфери, здатної забезпечити перехід мистецької взаємодії в новий, доступний для широкої громадськості формат.

Зроблено висновок про те, що культурна взаємодія між офріційними Брюсселем та Києвом характеризується певною хаотичністю, а отже, потребує систематичності, ініціативності в проведенні міжнародного діалогу та залучення широкої громадськості.

Ключові слова: Україна, ЄC, COVID-19, пандемія, культура, культурне співробітництво, міжкультурний діалог. 
The problem statement. The introduction of the strict quarantine restrictions, aimed to prevent the negative effects of the COVID-19 pandemic, has significantly complicated international communication processes. New challenges for cooperation have had a negative impact on almost every area of their interstate cooperation. And cultural sphere was not an exception, attention to which is often neglected, giving the priority to economic and political issues.

Intensification of cultural cooperation between Ukraine and the EU is one of the mandatory requirements of the Association Agreement 2014. Thus, common cultural development and creative links are one of the determining factor in Ukraine's integration into the Union. In connection with the total "lockdown" cultural dialogue between the parties requires careful rethinking and finding a new format that will provide understanding and support between official Kyiv and Brussels in the period of "isolation", prevent Ukrainian discredit in the international information system and form the country's positive image as well as create new opportunities for regional cultural interactions.

The analysis of current research works and publications. The peculiarities of cultural cooperation between Ukraine and the EU member-states were covered in the studies of some Ukrainian and foreign scholars, in particular modern Ukrainian researcher O. Domanska made an attempt to prioritize the directions of Ukrainian cultural cooperation [3] and O. Gladysh, which presented the peculiarities of cultural interaction with the Union in the context of the Creative Europe program [5]. The problem of cultural cooperation between Ukraine and the EU in the context of COVID-19 pandemic is quite new, and therefore isn't studied enough. However, the researches of Cultural Bridges [8], House of Europe [20] and the Creative Europe program [13] have made an attempt to identify the impact of the quarantine restrictions on the cultural activities of the parties with the aim of tracking the development of the cultural sector in the countries. A particular impact on the issue studies has been made by the representor's of Ukrainian and European media, such as Euronews [23], BBC Ukraine [2] and Ukrainian Time [10].

Identification of unsolved parts of the overall problem. Though the mentioned authors and analytic organizations made attempts to research the cultural cooperation between Ukraine and the EU member-states as well as impact of the quarantine restrictions on cultural and creative industries in the area, the issue of cultural cooperation reforming and adaptation to the new challenges caused by the pandemic still has to deal with the lack of structured ideological basis. As the result the problem research was not followed by practical aspects of cultural strategy development, in particular - the target cultural spheres and activities, successful manifestations and reforms as the response to quarantine restrictions and possible international view at these implementations.

The purpose of the article is to identify and to analyze potential possibilities for the development of cultural cooperation between Ukraine and the EU in the context of peculiarities of the interstate interaction functioning during COVID-19 pandemic. The goal will be achieved by implementing the following tasks: to examine the changes in the cultural sectors of Ukraine and the EU states, caused by COVID-19 pandemic; to suggest potential approaches to cultural strategy development and potential ways of strengthening cultural cooperation between the parties in the context of pandemic restrictions.

Basic part of the research. The EU's motto "Unity in Diversity" as one of the official symbols of contemporary most advanced organization reflects its key idea: the integration of diverse peoples and cultures for keeping peace and prosperity on the continent. It is the cultural unity of Europeans that determines the integration integration factor of the 27 states, which democratic values and experience in building an effective political system are sought to be adopted by young developing countries.

Choosing the pro-European way of development by signing the Association Agreement with the EU in 2014 and enshrining in the State Constitution the irreversibility of the EU integration path in 2019 Ukraine has assumed responsibility for expanding cooperation with the Union. Chapter 17 of Section V of the Agreement provides mandatory cultural cooperation between the parties which includes promotion of intercultural exchange, development of the art sector, cooperation within UNESCO and Council of Europe, as well as Ukrainian participation in the European program called "Cultural Europe" [9]. In the context of these obligations in the period from 2014 to 2018 a number of projects aimed at the development of the creative sector were implemented by the joint efforts of the parties. An important role in conducting common projects belongs to the Creative Europe program, which supported the implementation of the following initiatives: "Colab Quarter" - the creation of cultural spaces to deepen interaction between citizens; "Areas of Inspiration" - the creation of network of art residencies; "POLYPHONY" - recording, preservation and spreading of Ukrainian folklore; "Brave Kids" an artistic exchange between children from different countries [7]. In addition, it is worth mentioning the project "Culture Bridges" which was successfully creating new opportunities for expanding connections between cultural institutions in Ukraine and the EU from November 2017 to July 2020 [21].

However, despite such an ambitious start of cultural cooperation between the parties, the rapid spread of COVID-19 and human disability to counter new biological threat have forced political leaders to reorient on economic and social issues rather than solving 
intercultural problems. So new quarantine conditions have deeply changed the peculiarities of art sphere functioning in both Ukraine and the EU.

In the context of economic destabilization and uncertainty, each of the parties basing on value priorities and budgetary opportunities, independently determined the role and place of culture in terms of total lockdown. The EU's international cultural adviser Damien Helly's verbal comparison of culture that will cover the ruins like the seeds of flowers [19] exactly represents the European countries policy regarding the development of art in times of the crisis. Thus, Western Europe not just doesn't stay indifferent to cultural development, but also also significantly supports the creative sector. For example, Germany has launched a plan aimed at helping cultural actors and institutions, which provides social security and postpones the deadlines for mandatory payments. Danish parliaments have increased the planned expenditures to support small and medium cultural institutions. Finally, in Austria, artists will receive up to 2,000 euros as a financial quarantine aid [1].

In contrast to Europe, under conditions of quarantine restrictions, cultural and creative activities in Ukraine are suffering almost complete cessation due to the lack of an appropriate funding. After the announcement of the Ukrainian Ministry of Finance's intention to reduce the amount of financial support for absolutely all areas of cultural activities on March $28^{\text {th }}$ Ukrainian artists organized the first online rally "No - to the cultural destruction" aimed at protesting against such a rapid decrease of the cultural budget. Well-known Ukrainian artists, politicians and civil activists such as Yulia Sinkevysch, Maryna Kudernyk, Anton Drobovych, Irma Vitovska and Mykola Knyazhytsky joined the event [14]. However in April, the Parliament of Ukraine decided to make changes to the Budget 2020. In order to strengthen the economic and social sphere the deputies reduced the provision of the Ministry of Culture by 7 billion and the Ministry of Education by 3 billion [2].

As the lack of possibility to accurately predict the duration and the consequences of a pandemic significantly complicates the planning and implementation of cultural cooperation between Ukraine and the EU, the creative sectors of the both parties will inevitably feel the negative impact of the quarantine restrictions and global destabilization. However, the search for a new format of cultural cooperation in contemporary circumstances creates two main favorable factors for the further development of cultural connections between the parties.

The first positive factor is a rapid informatization of the society. The need of search of new possibilities for communication caused an active use of the Internet for implementing international projects, holding summit meetings, distant exchanging of cultural heritage as well as ensuring the continuity of the educational process [4].
The second positive factor is the ideological integration between the citizens of Ukraine and the EU. Common social and economic problems caused by the pandemic, as well as the awareness of the need for continuity of the cultural policy united cultural actors, volunteers and those, who are simply not indifferent, around the common idea [6]. So such integration contributes to the strengthening of cultural connections between Ukraine and Europe. Moreover thanks to the global network, such associations can easily spread the information about performed activities, hold cultural events online and involve the general public.

The use of these two factors creates a number of prospective opportunities for the development of cultural cooperation between Ukraine and the EU during the COVID-19 pandemic. As most of the existing European cultural programs are aimed at involving only member states of the Union, Ukraine should take the position of the initiator of cultural interactions with the EU. Such a position will be able to shape the image of Ukraine as a cultural center of the Eastern Europe, attract foreign investment as well as create new and strengthen existing cultural ties between our country and the EU member states.

We believe that potential ways should be considered in the context of three main objective of EU cultural policy: preservation of cultural heritage, promotion of intercultural dialogue and the development of cultural industries [2].

The cooperation in the field of cultural heritage is not only a prospective way of intercultural interaction between Ukraine and the EU, but also an opportunity to fill the European information space with the information about the past and present of Ukraine. The intensification of communication between the parties in this field is mainly caused by the Europeans' interest in Ukrainian culture as "something unknown" [10], so the results of such projects (whether successful or failed) directly affect the image of Ukraine in the minds of European citizens. It is important to mention that such projects can be oriented as at all of the Union member states, as at one or few of them. In particular, events which are aimed at involving some countries have to base on common European values and at the same time give possibilities to its members to demonstrate their national cultural peculiarities. The examples of such kind of projects can be international master classes and competitions in music, choreography and arts.

Another approach is to establish cultural cooperation directly with an individual EU country. The implementation of such projects requires a detailed analysis of the historical and cultural features of a particular state, the characters and mentality of its citizens and their level of interest in participation. Such projects should be based on common interests and cultural characteristics. What's more important these programs can perform two tasks at once: spreading 
information about cultural heritage and developing creative industries. For example, at the beginning of quarantine the world was fascinated by the virtual Louvre. The idea later inspired a number of other European museums, including the Dali Museum in Spain, the Vatican Museum, the Uffizi Gallery in Italy, the Belvedere Palace in Austria and much more. Ukrainian museums have also joined the virtualization, in particular the Dnipro National Historical Museum [18], the museums of Ostrovsky [12] and Dubensky castles [17], Literary-Memorial museum of G. Scovoroda [16] and so on. Moreover the memorial-museum "Lonsky Prison" [15] and archeological museum "Ancient Aratta-Ukraine" [11] in the village of Trypilla created virtual tours through its halls. Some of the museums, in particular the Khanenkys Museum" made a series of podcasts and began an active work on a YouTube channel [13]. Based on mentioned, it is worth assuming the feasibility of thematic cooperation between these museums in Ukraine and Europe to create a comprehensive representation of the historical and cultural area, and demonstrate the participation and influence of Ukrainians in European processes from the ancient times to nowadays.

Continuing the topic of development of cultural and creative industries, it should be noted that the informatization of society has not been able to reformat all areas of art. Ukrainian and European theater artists have made several attempts to "revive" theatrical performances by broadcasting them online. For example, Kyiv Wild Theatre created zoom-presentations [13] and organization European Theatre Convention has released recordings of performances of 2016-2019 years and used a temporary quarantine easing to stream performances [22]. The same situation often happens with the cinema art. The production of domestic and foreign films has partially stopped. Due to the quarantine restrictions, cinemas were forced to close indefinitely, and at the times of the quarantine easing - to decrease the ticket prices significantly. Nevertheless, the owners of European cinemas claim that the pandemic restrictions made it possible to diversify their offers to viewer by adding films that have already been released [23].

In our opinion, in such context an actual option for cinema cooperation may be the organization of international cinematographic exchange by creating an Internet platform containing films produced by Ukraine and European countries or holding a film festival online.

In addition, watching movies via such Internet platforms can be accompanied by a small payments or charitable contributions that will support at least partially the film industry during the pandemic.

Regarding other ways to support the development of cultural industries, it is worth mentioning the European cultural program "COVID-19 response", aimed at supporting culture and creative industries during the pandemic. This program includes a number of projects, which thematic circle is oriented at the search and implementation of anti-crisis ideas of cultural cooperation [20]. It is important, that Ukrainians also have the opportunity to participate in these projects, so in this context, the main task for Ukraine is to involve artists and young start-uppers in the development and implementation of ideas.

The development of cultural industries during the pandemic is impossible without the involvement of the IT sector. Wide possibilities of modern information technologies can ensure the development of the concept of "online tourism" and its implementation in the public consciousness of Ukrainians and Europeans. We have considered it worthwhile to create an Internet planform through which the general public in Ukraine and Europe will have access to the art of all countries participating in the intercultural interaction. An example of such implementation can be the Polish cultural program "100 days 100 events". The only difference will be in the number of countries conducting the promotion and the online format of the events.

Intercultural dialogue is an important integrational tool. The most common manifestations of such intercultural dialogue in the period of quarantine restrictions are bilateral communication between the representor's of educational institutions, mostly of higher education institutions. Nevertheless, public organizations, cultural associations and even ordinary people have the need for such communication. In this case intercultural dialogues directly depend on the initiative of the members of these associations and organizations. Therefore the leaders of Ukrainian educational and cultural institutions should understand the need of involving European partners in the dialogue, because in the context of isolation, any international initiative can become the first step towards a totally new dimension of cooperation.

Emphasizing the development of intercultural dialogue, it is also worth noting the need of informing the European community about cultural events and initiatives taking place in Ukraine. In the light of global trends of using Internet resources in diplomacy, we consider it appropriate to create a page of the Ministry of Culture of Ukraine in social networks, in particular in Twitter, Facebook and Instagram. In our opinion it is also important to maintain the regularity and relevance of publications on the pages as well as to interact with informal cultural actors in Ukraine and Europe in order to show the participation of the government agencies. Despite the lack of financial resources, we have to support at least the formal intercultural dialogue between Ukraine and the EU countries.

The conclusion and perspectives for further research in this area. It should be noted that cultural cooperation between Ukraine and the EU in the context of COVID-19 pandemic has signifi- 
cantly decreased. Due to the quarantine restrictions states were forced to postpone or even cancel most of the cultural events. However, the search for new ways of international cooperation using information technology has shown that conducting international events in the isolation is not only real but also quite successful. Cooperation in the frames of the EU's "strategic triangle" - fields of cultural heritage, intercultural dialogue and the development of cultural industries - requires the active involvement of governmental agencies, representatives of cultural and educational institutions and the general public. However most of such cooperation require regularity and initiative. Therefore, the active use of Ukraine's soft power to form an international image as a "reliable partner" and the involvement of European society in cultural cooperation with Ukraine require Ukrainians to take "the first step", put a great creativity and awareness to support intercultural dialogue with the EU. Also it is important to mention that international cultural interactions depend not only on governmental structures, but also from enterprising and active citizens.

Despite the radical changes in the attitude of Ukrainian society to the development of cultural cooperation with the EU, the official Ukrainian policy (including the European direction) is characterized as having a certain chaos. So the issues of prioritization of international cultural cooperation in the context of the COVID-19 pandemic which contain the involvement of non-governmental organizations and the general public as well as the search for new ways of cultural interaction in the frames of the quarantine restrictions become quite prospective areas for further research.

\section{REFERENCES:}

1. Бадор Д. Культура в часи пандемії: як європейські країни рятують креативні індустрії. LB.UA. 2020. URL: https://lb.ua/culture/2020/04/04/454508_kultura_chasi_pandemii

2. Бюджет 2020 і коронавірус: Верховна рада перекроїла видатки і створила спецфонд. BBC News Ukraine. URL: https://www.bbc.com/ukrainian/news-52269568

3. Віртуальна екскурсія літературно-меморіальним музеєм Григорія Сковороди. URL: http://incognita.day. kyiv.ua/virtualna-ekskursiya-literaturno-memorialnim-muzeyem-grigoriya-skovorodi.html

4. Віртуальний тур Дубенським замком. URL: http://incognita.day.kyiv.ua/museums/dubno/

5. Віртуальний тур по музеям. URL: http://www.museum.dp.ua/virtual-tours.html

6. Гладиш О. Культурне співробітництво України та ЄС: програма ЄС «Креативна Європа». Актуальні проблеми міжнародних відносин та міжнародного права: матеріали Всеукраїнської наук. онлайн-конф. Київ : Київський університет ім. Бориса Грінченка, 2020. С. 222-226.

7. Громадянське суспільство в умовах пандемії COVID-19: як організації справляються 3 новою реальністю. UKR.Inform. 2020. URL: https://www.ukrinform.ua/rubric-presshall/3019971-gromadanske-suspilstvo-vumovah-pandemii-covid19-ak-gromadski-organizacii-spravlautsa-z-novou-realnistu-prezentacia-doslidzenna.html

8. Департамент стратегічного планування та макроекономічного прогнозування. Консенсус Прогноз «Україна і вплив COVID-19 на економіку та суспільство». 2020. № 52.

9. Доманська О. Україна і міжнародне культурне співробітництво. Вісник НАКККІМ. 2014. № 3, С. 28-33.

10. Креативна Україна в контексті програми ЄС «Креативна Європа». TOGETHER Європейський простір: веб-сайт. 2018. URL: https://euprostir.org.ua/practices/134281

11. Кузнєцова Д. 5 пріоритетів культурної політики ЄС. Асоціація «Культура і креативність»: веб-сайт. 2020. URL: https://www.culturepartnership.eu/ua/article/cultural-policy-priorities

12. Культура. Євроінтеграційний портал: веб-сайт. URL: http://eu-ua.org/yevrointehratsiia/kultura

13. Культурна дипломатія України: яскравий старт і амбітні плани. Ukrainian Time: веб-сайт. URL: https:// ukrainiantime.org/uk/article/kulturna-dyplomatiia-ukraiiny-iaskravii-start-i-ambitni-plany

14. Музей «Прадавна Аратта». URL: http://incognita.day.kyiv.ua/museums/trypillia

15. Острозький замок 3D. URL: https://ostrohcastle.com.ua/3Ddonjon/index.html

16. Семенюк О. Як карантин вплинув на культурні індустрії. Creative Europe: веб-сайт. URL: https:// creativeeurope.in.ua/posts/quarantine-influence-on-cci

17. Тюрма на Лонського. Віртуальна екскурсія. URL: http://www.lonckoho.lviv.ua/ekspozytsiya/ pershyj-etap-ekspozytsiji/virtualnyj-tur-pershym-etapom-ekspozytsiji

18. Щур М. Митці України виступили проти скорочення видатків на культуру. Radio Cвобода: веб-сайт. URL: https://www.radiosvoboda.org/a/mytsi-proty-skorochennia-kostiv-na-kulturu/30513723.html

19. Carlsson R. Culture, Coronavirus and the Future of UK Museums. URL: https://www.museumnext.com/ article/culture-coronavirus-and-the-future-of-uk-museums/.

20. COVID-19 response. House of Europe. URL: https://houseofeurope.org.ua/en/grant/covid-19-response

21. Culture Bridges. URL: https://www.britishcouncil.org.ua/programmes/arts/culture-bridges

22. Online Showcase. Performance Exchange Program. European Theatre Convention. URL: https://www. europeantheatre.eu/page/activities/international-professional-development/performance-exchange-programme/ online-showcase

23. Tidey A. Cinema's Struggle for Survival amid Coronavirus and Hollywood Delays. URL: https://www.euronews. com/2020/10/12/cinema-s-struggle-for-survival-amid-coronavirus-and-hollywood-delays. 